\title{
Tamalola
}

\section{Transregional connectivities, Islam, and anti-colonialism on an Indonesian island}

\author{
HANS HÄGERDAL AND EMILIE WELLFELT
}

\begin{abstract}
The present study focuses on a set of events in the Aru Islands, Maluku, in the late eighteenth century which are documented in some detail by Dutch records. A violent rebellion with Muslim and anti-European overtones baffled the Dutch colonialists (VOC) and led to a series of humiliations for the Company on Aru, before eventually being subdued. As one of the main catalysts of the conflict stands the chief Tamalola from the Muslim island Ujir. Interestingly, this person is also a central figure in local traditions from Ujir. Moreover, his story connects with wider cultural and economic networks in eastern Indonesia. Thus the article asks how the imprints of the Tamalola figure in textual and non-textual sources can add to our knowledge of how communities of Eastern Indonesia ordered their lives outside colonial control.
\end{abstract}

KEYWORDS

Ujir; Aru Islands; Maluku; VOC; rebellion.

\footnotetext{
HANS HÄGERDAL currently holds a position as Professor in History at Linnaeus University. He has worked on indigenous societies and colonial encounters in Eastern Indonesia. In particular, he has looked at the methodological problems and possibilities of writing indigenous history, using a concurrence of colonial data, oral tradition, and material remains. The present study was conducted in the context of a research project funded by the Linnaeus Center for Concurrences in Colonial and Postcolonial Studies. Hans Hägerdal can be contacted at: hans.hagerdal@lnu.se.

EMILIE WELLFELT has worked on documentation of language, culture, and history among the Ujir-speaking community in Aru during five periods of fieldwork, each lasting between two weeks and three months in the period 2013-2018. The documentation was conducted for the Aru Languages Documentation Project of Cologne University, which was part of the DoBes (Dokumentation bedrohter Sprachen) initiative, funded by Volkswagen Stiftung. Work on this article was undertaken when Wellfelt held a position as post-doctoral researcher at Stockholm University. Emilie Wellfelt can be contacted at: ewellfelt@gmail.com.
}

(C) 2019 Faculty of Humanities, Universitas Indonesia

HANS HÄGERDAL AND EMILIE WELLFELT | DOI: 10.17510/wacana.v20i3.802. 


\section{INTRODUCTION}

Towards the end of World War II, Maiabil, the main village on the Island of Ujir in the north-west of the Aru Archipelago, was bombed by the Australian air force, perhaps on the assumption that Japanese soldiers were hiding there. The villagers fled into the surrounding forest, and before they dared return one woman gave birth to a boy who was subsequently called Lari Hutan, Malay for 'Run into the Forest' ${ }^{1}$ His proper name is Ali Walai and seventy years after the war ended, he was one of the few who still remembered living in the old village Maiabil, meaning 'inside water' in the local Ujir language. For centuries, the village, situated alongside a saltwater channel, served as a strategic location, offering shelter from winds and waves and defence against enemies, with the exception of a disastrous attack by the Dutch in 1790 .

Maiabil was demonstrably not the same safe haven one and a half centuries later when aggressors attacked from the air. After the war, people began settling on the western beachfront of Ujir Island and the old village slowly disintegrated into an overgrown ruinous area, interesting to archaeologists but rarely visited by anyone from the new village. Among the vines and trees that cover the site, a few places of memory stand out. One is the old mosque; Ujir is the traditional centre for Islam in Aru. Another is the World War II bomb crater, allegedly, the only living creatures hit by the bomb were some grazing goats. A third memorable place is a rectangular stone foundation. On this once stood the home of the revered ancestor Tamalola, protagonist in the events around which this article revolves (see Image 1). A wall-like structure that runs out from one of the corners of the house is alleged to be a passageway through which Tamalola entered and left the house. ${ }^{2}$ Interestingly, Tamalola stands out in both oral tradition and written historical documents as a local strongman, and his death can be exactly dated to 1783 , towards the end of the dominance of the Dutch East India Company (VOC) over what is now Indonesia. Moreover, he or the imprints that he made on the collective memory, had a role as a catalyst in a rebel movement that nearly wiped out Dutch colonial power in the Aru Islands and beyond in the years 1787-1791. The vengeful acts committed in his name resulted in a unique attempt to introduce an Arunese kingship and to utilize the Maluku-wide prestige of the age-old Tidore dynasty from another part of the same region. As his story therefore connects with wider cultural and economic networks in Eastern Indonesia, the article asks how the imprints of the Tamalola figure and the rebellion in textual and non-textual sources can add to our knowledge of how local communities in Eastern Indonesia defined their own place in this world, how they ordered their lives outside colonial control and how they networked with proponents of anti-foreignism on a supra-local and larger regional level.

1 In Eastern Indonesia it is a common practice to give children both a "village name" (Malay: nama kampung), often inherited from a grandparent or descriptive of events around the child's birth, and a formal name which is used in official records.

2 Information on the spot by villagers of Ujir, 9-4-2016. 


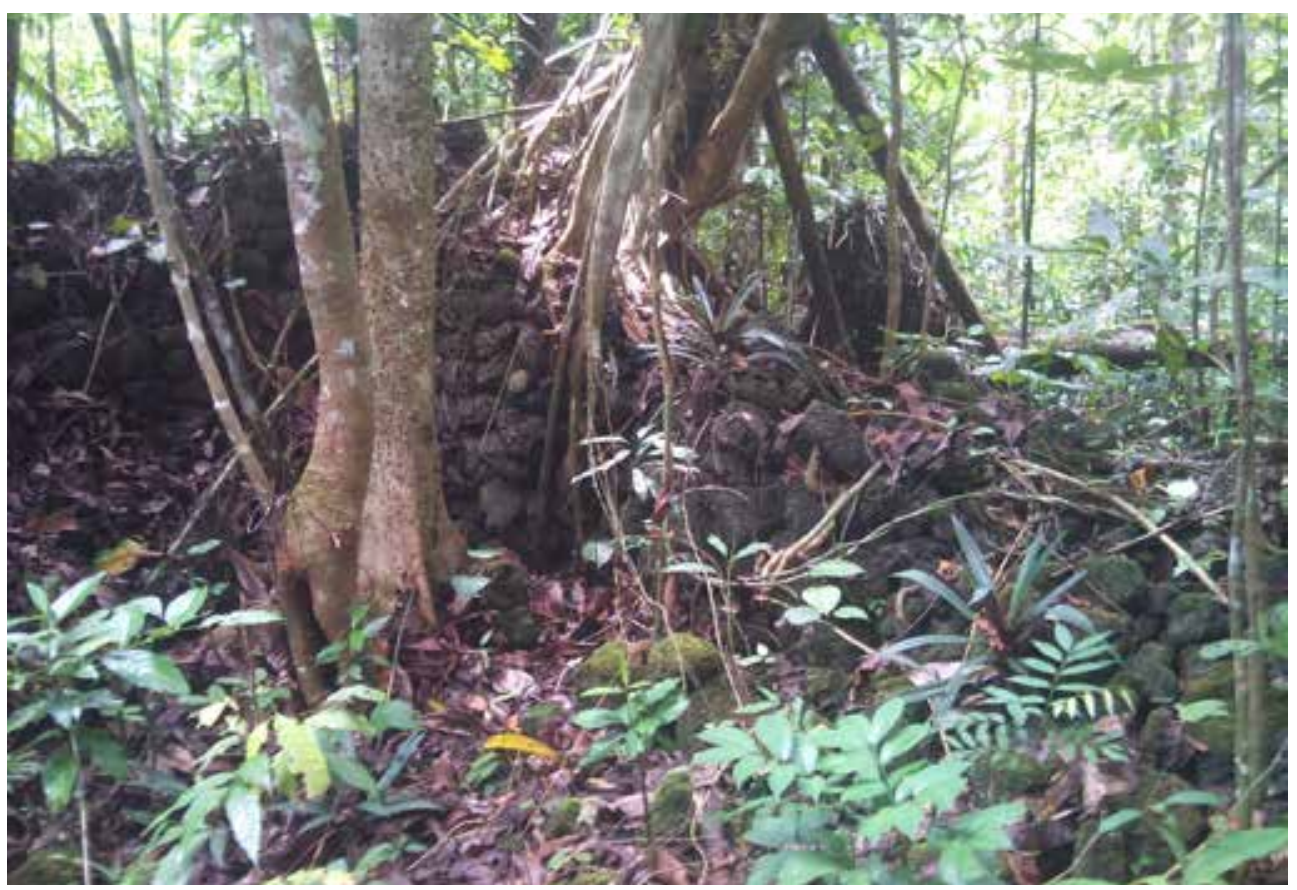

Image 1. Ruins of a stone building in the abandoned village Maiabil on Ujir, said to have been the residence of Tamalola (photograph by Hans Hägerdal).

\section{SitUATING UjIR}

Before telling Tamalola's story, it is necessary to devote a few more words to the island on which he spent most of his life. Ujir is a flat, largely forested island of insignificant size, lying on the western side of the Aru Islands in South Maluku, some 200 kilometres south of Papua. ${ }^{3}$ Its modest appearance and tiny population hides an intriguing past that ties it to several wider historical processes, including global trade, European colonialism, and Muslim and Christian expansions into maritime Southeast Asia in the early modern period.

Early accounts of Ujir written by Europeans convey a superficial idea of marginality blended with engagement with outside forces. The Dutch military official Dirk Hendrik Kolff visited the island in 1825 in order to make peace between the Ujirese and another settlement. The inhabitants appeared to have few needs, although the visitors found them more "restless" than other Arunese. They grew sago and yams for their own consumption, while traders from Makassar, Kei, and Gorom brought them rice, as well as cloths, porcelain, metal tools, arrack, beads, and similar items. As were the other west coast settlements of Aru, Ujir was a trade post for luxury goods such as trepang (sea cucumber) from the eastern side, intended for export to other parts of Asia. The riches of the Ujirese consisted of slaves, firearms, gongs, and elephant tusks, but their dwellings were very modest. Although they were all Muslims and

3 The Aru group encompasses 6,269 square kilometres, therefore it is much larger than, for instance, Bali. Ujir is no more than a few square kilometres. 
less enthusiastic about Dutch suzerainty than the Christian Arunese, they got on very well with the last-mentioned, even assisting them to build churches. But Kolff also observed that there were indications of a more prominent past on Ujir: in the old village we know as Maiabil he found traces of a long street running through the main settlement, enclosed by walls and lined with the ruins of several stone buildings. The Ujirese did not give any clear answers to the questions Kolff posed about the origin of the remains (Kolff 1840: 206-216). Accounts such as that of Kolff give an admittedly vague idea of Ujir's, and Aru's, inclusion in a number of economic and cultural contexts. The Ujirese might have been poor by European standards, but they also transferred luxury products to the outer world.

\section{THE LIFE AND DEMISE OF AN ARUNESE ORACLE}

In Ujir collective memory, the ancestor Tamalola is remembered as a benevolent ruler who cared for his people and was loved in return. Some of his descendants keep a large brass kettle as an heirloom passed down from him (see Image 2). It is said that the kettle was used to serve hot beverages to the people, while Tamalola himself was served from a silver pot, and that the water in his pot was heated by burning silk cloth - Tamalola was so rich he could use expensive imported textiles instead of firewood. ${ }^{4}$

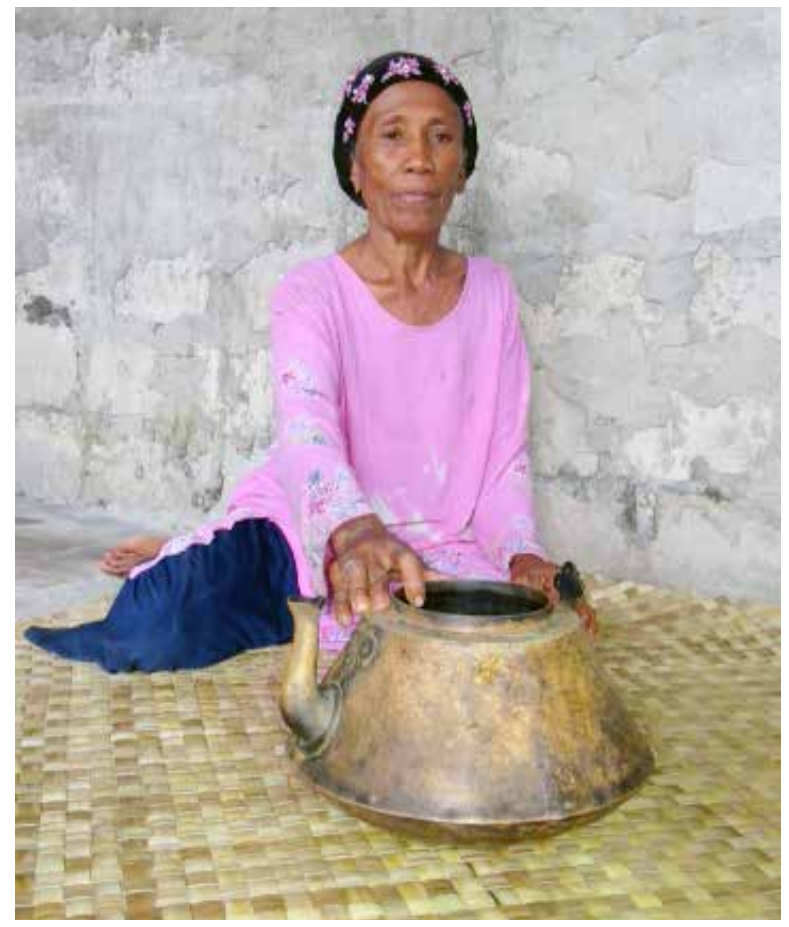

Image 2. A large brass kettle that was, according to tradition, used by Tamalola to serve hot beverages to the people (photograph by Emilie Wellfelt).

4 Interview with Ajaka Baubesi, keeper of Tamalola's kettle, Ujir 2015. 
An account from 2012 based on oral tradition relates that Tamalola co-operated with the "Portuguese" (probably just meaning the white foreigners). In the end, he died and was buried on Banda Neira, one of the islands of the Banda Archipelago. His grave near the harbour of Banda Neira is still pointed out by the locals. ${ }^{5}$ There are a few pedigrees that trace later persons back to Tamalola. One 1913 account gives six generations from Tamalola, while one recorded in 2016 has nine. ${ }^{6}$ Counting twenty-five years per generation, this would take us back to the second half of the eighteenth century, which happens to be correct. ${ }^{7}$

There is a huge step from local collective memory to the regular, ostensibly scrupulous reports penned by the VOC authorities in Banda, whose duties also included monitoring conditions in faraway Aru. The VOC was a commercial organization but also a proponent of early colonialism, that scrupulously watched over its monopolies of products and routes. When strategic issues were at stake, the Company employees would sometimes go to great lengths to investigate local matters. As it so happens, much of Maluku was in an agitated state in the years around 1780, as will be explained later. One figure who comes to the fore in the texts is Tamalola, an orangkaya (chief, lit. rich man) who governed over one of the kampungs on Ujir. A report makes clear that he was beloved of the Ujirese. ${ }^{8}$ Moreover, as a Dutch witness says, "This old Imam, who was also the main regent and noted as the Oracle of Aru, was the only person who descended in the direct male line from the old orangkayas and regents of the land who had concluded advantageous contracts with the Company for 132 years". ${ }^{9}$ He was held in high esteem on account of his personality, as well as because of his family background (Bleeker 1858: 268). He first appears in the sources in 1779 when another orangkaya from Ujir called Sabetu turned up in the governor's quarters in Banda with startling news. Sabetu would later rebel against the Dutch, but this was before the outbreak of the Maluku-wide Nuku rebellion (1780-1797) and the chief had no hesitation in playing the Dutch off against his fellow-villagers. He told the governor of an ostensibly treacherous orangkaya Abdul, and also warned against the designs of orangkaya Tamalola, who was on his way to Banda for a trading expedition. After his affairs on Banda had been concluded, asserted Sabetu, he was planning to join Abdul in Seram and collude with people from Seram, Gorom, and Papua who were hostile to Dutch domination. The governor accordingly arrested Tamalola on arrival and launched an investigation. Eventually it was found that the accusations were baseless, and the orangkaya was released and sent on his way with a few gifts. ${ }^{10}$ The story points to the fragmented nature of stateless and unstratified societies. It was difficult to achieve unitary strategy as there were few checks on the internal conflicts

\footnotetext{
Afifudin Manja, manuscript, 4 January 2012. Translation by Emilie Wellfelt.

Müller Wismar, fieldnotes, 1913, f. 87; information by Bapak Taha, Ujir, 9-4-2016.

Under certain conditions, transmission of genealogies can be stable in the oral traditions of Eastern Indonesian societies; see Fox 1971.

8 VOC 8034 (1789), Report, 30 July 1787, f. 115.

9 ANRI Banda: 45-1, Report dated 1796, Arsip Nasional, Jakarta.

10 VOC 3864 (1789), Secret letter, 6 December 1788.
} 
that inevitably arose. This would be remedied a few years later by taking the radical step of summoning a king to the small island, a partial consequence of Tamalola's unkind fate.

By 1782, the Dutch had begun to fear for the growing influence of the rebel movement of the Tidorese prince, Nuku, who pursued a strongly antiEuropean agenda, and whose tentacles were palpable even in South Maluku. There was a danger that Nuku might influence Aru, whose Muslim population the Dutch thought untrustworthy. ${ }^{11}$ The next year brought more bad news. Rumour had it that Nuku planned to settle on Aru should he need refuge from his Dutch adversaries. A cruiser returning to Banda from Aru in May 1783 brought the news that some chiefs on Muslim Ujir had communicated with the enemy. Perhaps they intended to abandon the Company and the Banda burghers altogether and allow the creed of the Prophet triumph on these islands. As the crew of the cruiser understood it, Tamalola was the most prominent chief who supported this "destructive aim". ${ }^{12}$ The worrying nature of the report led to the dispatching of a commission headed by Willems and Clements accompanied by some military personnel. ${ }^{13}$ The details of the following events are not clear to us, but the commissioners managed to arrest Tamalola "handily", apparently without much commotion. The "crafty" Tamalola tried to buy his way out of the situation by offering the Dutch gifts, four slaves, ten pounds of edible bird's nests, and some elephant's tusks, in return for his freedom. His machinations fell on deaf ears; the bribes were promptly confiscated by the commissioners and he was taken to Fort Belgica in Banda where he was incarcerated. The idea was that the orangkaya be dispatched to Batavia where the authorities would decide his fate. However, Tamalola stubbornly refused to eat and eventually passed away on 15 July 1783. Whether this was what we would call a "hunger strike", or had to do with his perceived impurity of the food served by the Christian Dutch, we cannot tell from the documents. Whatever the case, the Dutch did grasp that his death might cause trouble. They therefore took care to bury him in the manner prescribed by Islam, in the style befitting an indigenous regent, so that there would be no impression of disrespect. His gifts were sold at auction. ${ }^{14}$ As a VOC official wrote, with some self-justification:

During the detention of this old man, I gave him food and drink, ${ }^{15}$ providing this at the suggestion of the Moorish priest, Wattrouw, who was resident on Banda, with the knowledge of Governor J. Seidelman. Subsequently, this Moorish priest buried the body of Tamalola according to the custom of the Mohammedans [...] When the nephew or sister's son of this old regent later came to Banda on an indigenous craft, loaded with Arunese products to pay off his debt, and he heard

11 VOC 8028 (1782), f. 54-55.

12 According to the 1788 letter by s'Gravezande, the original accusation against Tamalola was lodged once again by Ujirese people; see VOC 3864 (1789), Secret letter, 6 December 1788.

13 Called Hageman and Willemsz in Bleeker 1858: 268.

14 VOC 8029 (1784), f. 117-120.

15 This assertion, of course, gainsays the story of Tamalola's "hunger strike". 
what had happened to his uncle and learned that I had asked for the remains of the old Tammelola in order to bury it in the Mohammedan way at the request of the Moorish priest, Wattrouw, he was furious about the fate of his uncle. He then came to me and hugged me with tears in his eyes, since I had cared for this old man. He remained with me for some time and promised repayment for [the funeral]. Among other tokens of friendship, he offered me a few pieces of karet [turtle-shell]. ${ }^{16}$

A later report complained about the clumsy way the matter was handled. The revered Tamalola had suffered unjust poor treatment at the hands of Willems and Clements. His arrest was carried out in an arbitrary fashion and with too little planning, so that the real principal troublemakers had the opportunity to flee. ${ }^{17}$ The life of Tamalola, as known from contemporary sources, is dramatic but not extraordinary; he was one of many local leaders in Maluku who clashed with the suspicious Dutch authorities. However, there are two trails that emanate from his person and imbue it with a larger local and regional significance. Firstly, his position in a local genealogical and cultural context; and secondly, the dramatic effects of his martyrdom as mirrored in contemporary sources.

\section{ORIGIN STORIES AS NARRATED IN 1913 AND 2012}

Ujir has a social organization that is based on groups called bén. In simple terms, these are collectives sharing rights and duties, but not kinship. Everybody living on Ujir is a member of a bén, outsiders who settle are incorporated into a bén but retain their own lineage or clan names. In the old village, Maiabil, there were five bén, in the new village that was established in the mid-twentieth century they merged into three, and in the course of that process the bén were named Walai, Bolibole, and Baubesi. ${ }^{18}$ Walai refers to the wali, or holy man, who brought Islam to Ujir, Bolibole (Bolbol) is a historical figure discussed later in this article, and Baubesi ${ }^{19}$ refers to the group who brought metal (besi) to Ujir, the settlers from Luang, Tamalola's kin.

Looking at local understandings of geographical connections, we find fascinating aspects of external ties that are not found in the colonial records. ${ }^{20}$ One point of origin for Ujir indicated by tradition is Luang, a small atoll to the east of Timor, belonging to the Luang-Sermata group. While almost unknown in Indonesian history, its inhabitants in fact exerted a considerable cultural and commercial influence in Eastern Indonesia. They were skilled goldsmiths and producers of pusaka (heirloom) objects, fished for trepang and sailed their ships over a large area, ranging from Dili in Timor to the Aru and Tanimbar Islands (Encyclopaedie 1921: 1435-1436). Some legends say that all

16 ANRI Banda: 45-1, Report dated 1796, Arsip Nasional, Jakarta.

17 VOC 8034 (1789), f. 115.

18 Interviews with the late Bapak Jafar Hatala $(2013,2014)$.

19 The etymology is supposed to be Malay [mem]bawa besi, literally translated 'bring iron'.

20 For the methodological possibilities of using oral data, see in particular Vansina 1965, 1985 and Spyer 2000. 
the peoples of Aru originally came from Luang, arriving on a giant mussel shell with eleven sails. ${ }^{21}$

Ujirese tradition, as recorded by the German researcher Müller Wismar in 1913, tells that the first ancestors were Kubal and his wife, Inte Rebuda, who appeared from a burning tree. Their daughter was Boitika whose blood flows in the veins of all Ujirese to some degree. Later, three clans arrived in Ujir from distant lands. The first was Jeriri, that originated in Malacca and travelled to Tanimbar and then to Hana. At the last-mentioned place they split: one member went to Ujir, one to Batuley on the eastern side of Aru and the third ended up in Kaanmai, also in the east. The second clan, Walai, departed from Malaya Koya and traversed the seas on their perahu Yansai, via Bone, Makassar, Buton, Banda, Gorom, Tidore, Papua Kabiau, and Wasir. The Walai converted the local population on Wasir to Islam before embarking on the final few kilometres to their ultimate destination, Ujir. The third clan, Kafosal (that is, Baubesi), consisting of seven siblings, left Luang on the ship Sinabesi (Iron Arrow) and arrived in the Kei Islands. The youngest brother, Kurbibi, went ashore on Kur to gather some edible fruits. However, he cut himself by mistake and his blood flowed onto the ground. He then decided to stay there. The other brothers were established on Danar, Tual, Har, Gorom, and Onin in Papua. A sister, Boiraten, remained on Banda where her grave could still be seen, and her descendants continued to reside either there or in Ambon. The remaining brother Boiniki came to Ujir where he converted to Islam and took the name Iburahim. The blood of the autochthonous people and the immigrants was subsequently mixed, since the daughters of Boitika married members of the Jeriri and Kafosal. ${ }^{22}$

It is interesting to compare this with an account written down a century later, in 2012, by a member of the Baubesi (Kafosal) bén. This account largely corresponds to the older one, but adds some substantial details. The migrants left Elmara in Central Luang, using a seashell as their vessel. One central point is that they carried along a clod of earth. After a stopover on the Keiese Island Har, Boiniki, and his sister Boiratan, together with ten Keiese retainers, sailed on to Aru. The little expedition explored the coasts trying to find the best spot to settle, and finally came to Jakalar in Ujir. Before they had stepped ashore, some roots for poisoning fish that they brought along, fell in the water and were miraculously turned into a reef. In a similar vein, the rudder of the vessel broke and fell into the water, likewise turning into a reef. After these startling events, the little crew went ashore and found that the earth matched the sample brought from Luang exactly. As the two soils united, it became possible for Boiniki to live at Jakalar, that was now considered the same as Luang. Hence Boiniki and his followers settled there, but soon found out that they were not alone on the little island. One day, when Boiniki's retainers went out for a hunt, they encountered two envoys of the female lord of the land, Rabudi, that is, the Inte Rebuda of Müller Wismar's account. The 
two men, who bore the Muslim names Yunus and Yusuf, only had arrows made from sugar-cane, inferior to the iron-tipped arrows used by Boiniki's men. The newcomers helped the envoys to hunt down a wild pig and, as a consequence, their respective masters Boiniki and Rabudi were introduced to each other. Rabudi allowed Boiniki's party to settle on Ujir against a payment of two gold pieces. The borders between the autochthonous people and the newcomers were then carefully fixed and commemorated in songs that are still remembered. Eventually Boiniki proposed to Rabudi who consented to marry him. Through this marriage, Boiniki acquired the status of ruler over Ujir, and his clan grew rapidly. ${ }^{23}$ Before continuing, it should be noted that the narration, as many oral and written traditions, is far from neutral. The last part especially, about Boiniki becoming ruler over Ujir, is controversial as it still has implications to do with power and inherited land rights.

It is common in local traditions in Eastern Indonesia for the origin of a polity to be related in great detail. This explains the position and relationship between various clans and functions. By contrast, subsequent generations are often little more than names. In the case of Ujir, however, a prominent father is followed by a prominent son, a son who also made his mark in the European records. At least according to some versions, Boiniki begot sons called Tamalola and Hasan. ${ }^{24}$ Tamalola was married to Tiba, a daughter of Inte Rebuda's daughter Boitika, while Hasan married another daughter called Numkana. However, another version has it that Tamalola lived a number of generations after Boiniki. ${ }^{25}$ The two versions might not be at odds, as discussed below.

(clan from Luang)

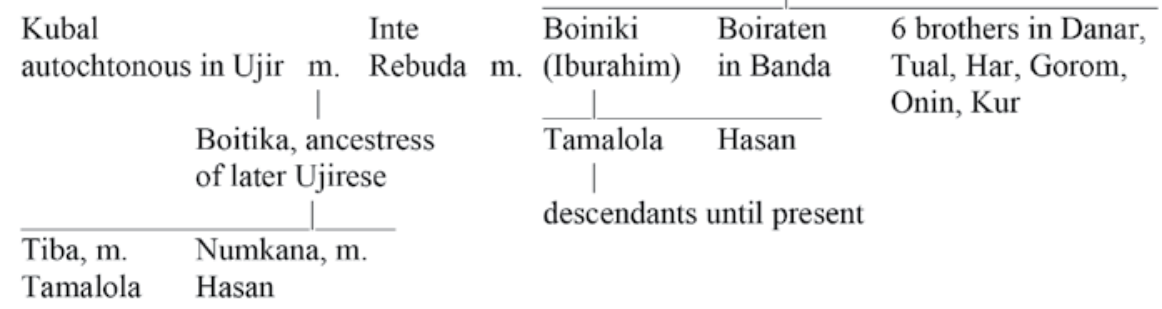

Table 1. Genealogy of Tamalola. The table shows the mythico-historical figures related to Tamalola, who were important for the formation of Ujir society.

Many elements in the accounts from 1913 and 2012 are also found in other contexts in Indonesia. The itineraries of ancestors, beginning in some prestigious place farther west, have parallels in, for example, the claim of the Timorese ritual centre Wewiku-Wehali to originate from Malacca, and the alleged Balinese origins of aristocratic families on Kei, and groups in Alor claiming origins from the famous Javanese kingdom Majapahit (Grijzen 1904:

23 Afifudin Manja, manuscript, 4 January 2012.

24 Müller Wismar, field notes, 1913, f. 87; information by Bapak Taha, Ujir, 9 April 2016.

25 Afifudin Manja, manuscript, 4 January 2012. 
18-19; Hooe 2012: 83, 87; Wellfelt 2016). The names found in the itineraries are important since they give an idea of the places that counted for something in the local Ujir perspectives. Seafarers from South Sulawesi and Buton were active in Eastern Indonesia, sometimes operating under the radar of the Dutch. Banda was economically important to Aru before as well as after the Dutch conquest. Gorom and Tidore both had a great impact in the history of Ujir, as we shall soon see. That Ujirese society emerges through mimesis, enjoying a sameness with Luang, is a variation on a cluster of origin stories in Aru, Kei, Leti, Roma, Sermata, Kisar, Wetar, and so on, that all point to Luang origins. This leaves Luang's role as a cultural and demographical point of origin to be explained, even though the island is known to have entertained an extensive commercial network in Portuguese Timor and Southern Maluku by the nineteenth century (Riedel 1886: 319).

Another element often found in various parts of Eastern Indonesia is the encounter between an autochthonous "lord of the land" and an immigrant lord, leading to a division of power in which the immigrant becomes the effective ruler while the original lord retains certain ritual roles and privileges (Fox 2008). In this case, the marriage between the two seems to blur the distinction between indigenous and outsider in subsequent generations. Oral traditions in other groups within the Ujir community underline the role of the autochthonous people who are the traditional keepers of the lands, the tuan tanah. While acknowledging the settlers from Luang, they contest the idea that the newcomers became rulers, and their concomitant claims to land rights that might follow. Moreover, the idea that Islam was introduced by the settlers from Luang is dismissed, maybe on good grounds as Luang never was Islamized (Wellfelt and Djonler 2019; Riedel 1886: 311).

\section{EARLY RELATIONS WITH THE DUTCH}

Eighteenth-century VOC officials underlined the peculiarities of Ujir in relation to the rest of Aru. The Dutch had an intense interest in a stable political situation that would secure their acquisition of luxury goods via a monopoly system of trade. Anything that disturbed this system was severely frowned upon in the colonial reports, and Ujir is a case in point. The inhabitants were castigated as troublemakers and their community was seen as detrimental to Aru. Their entertainment of relations with independent-minded communities in other parts of Eastern Indonesia only underlined their iniquity in Dutch eyes. ${ }^{26}$

While the negative judgements might say more about their European authors, the peculiar position and far-flung connections of Ujir do merit more attention. The small islands that are scattered throughout the southern parts of Maluku might have seemed marginal in relation to both the Western seafarers and the spice-producing places of Central and North Maluku, all the more so since they were stateless, tardy in their acceptance of world religions and 
often inaccessible. However, the islands also lay a crossroads where languages, cultural forms, belief systems, and innovations met and were transmitted (De Jonge and Van Dijk 1995: 19-29). The Aru and the nearby Kei Islands were tightly allied with the pre-colonial traders and nutmeg-producers of the Banda Islands, whom they supplied with provisions. The Portuguese chronicler Tomé Pires reports that Muslim traders had settled on the coasts of Banda and dominated trade there since the 1480s (Pires 1944: 206). The Portuguese were present in Maluku throughout most of the sixteenth century, but their influence was limited. The VOC was established as a joint-stock commercial company in 1602 and soon took over the role of the Portuguese as the main European force in Indonesian waters.

In 1619, a small fleet loaded with foodstuffs for Banda, that largely consisted of people from Ujir, was embroiled in a bloody confrontation with the VOC forces in Ambon (Tiele 1886: 264; Van Dijk 1859: 6). Two years later, in 1621, the VOC carried out the genocidal conquest of Banda and took over the Bandanese interests in the southern regions of Maluku. In Banda, the VOC proceeded to establish a Christian outpost. The main chiefs of Aru and Kei were approached in connection with a VOC expedition to Queensland and Arnhem Land in 1623, and it is now that Ujir Island is expressly mentioned in the documents for the first time. At that moment, the Ujirese-speaking settlements (negeri) Ujir, Tutafaning, and Fangabel (the last-mentioned situated on Wokam Island) signed a contract with VOC representatives, as did several other Arunese west coast settlements (Corpus 1907: 179-182). Whether there already were Muslim elements on Ujir in this period is not clear, but the previous connection with Banda suggests a certain knowledge about the religion.

The VOC had entered an area with many pre-existing allegiances. It has been established that Ujir was involved in the ritual division between an Ulisiwa (Ursia, the nine-bond) and an Ulilima (Urlima, the five-bond) faction, one found in many places in Maluku. As far as is known, Ujir was always Ursia (Gordon and Djonler 2019; Wellfelt and Djonler 2019). The Urlima, as the less numerous group, sought the protection of the VOC in 1646, and again in 1653 and 1659 (Coolhaas 1971: 402). As a consequence of this and other considerations, the Company built a fort on Wokam, not far from Ujir, and actively promoted the dissemination of Christianity in the west coast villages.

In spite of the early contracts, competitors were still contending for influence on the islands. Although not a part of the far-flung Sulawesi-based Makassar empire (Gowa-Tallo'), Aru received frequent visits from seafarers from Sulawesi, who began to propagate a Sufi form of Islam from the early seventeenth century (Laffan 2011; Coolhaas 1960: 166-167). Moreover, Muslim refugees from Banda came over to Aru after 1621 and settled there. As related in travel accounts from 1646, the Bandanese exiles did their utmost to incite the locals against the Dutch. ${ }^{27} \mathrm{~A}$ few years later, Islam was introduced into 
part of Ujir in 1650-1651, and it is claimed in the Dutch records the reason was the shipping run by the Makassarese before they were interrupted by the VOC victory against Gowa in 1667-1669. ${ }^{28}$ The role of Makassar Islam in Ujir is nevertheless rejected by present day oral traditions (Wellfelt and Djonler 2019). Interestingly, the islanders sought the spiritual advice of the well-known German naturalist Georg Rumphius who was residing in Ambon and enjoyed a good reputation among local populations of all denominations. Envoys were sent to Ambon in 1668 asking Rumphius to arrange for an Islamic teacher to be dispatched there. Although the request did not produce any result, it does highlight a fairly open-ended approach to religious knowledge. ${ }^{29}$ Hence, the Ujirese people demonstrated a wish to become Muslims that was not followed by other Arunese, since the west coast villagers in Wokam, Wamar, Trangan, and Maekor preferred to bond with the Christian teachers sent by the VOC. There is in fact a striking concurrence between the introductions of the two religions in the 1650s, one that is hardly coincidental. It is possible to draw the conclusion that religious and commercial dynamics were closely intertwined in local politics. A document from 1636 shows that the Ujirese were striving to acquire the colourful carcases of the valuable birds-of-paradise, apparently to sell to outsiders (Dagh-Register 1899: 227). In 1674 the VOC corporal and the Christian teacher in Wokam village reported to the Banda authorities that two ships from Buton were trading in Ujir. The orangkayas (chiefs) of the place had sent birds-of-paradise and a substantial cargo of sago to the king of Buton, sago being a staple foodstuff in regions with limited rice production. ${ }^{30}$ Buton was a seafaring kingdom of some consequence and was having troubled relations with the extensive Ternate Sultanate in this era (Zahari et al. 1977: 62-65). It is indeed remarkable that the vibrant but small Ujir community established a direct link with the Butonese ruler. This event concurs with local oral traditions about Islamization in Ujir. According to this, seven holy men left Mecca to spread the word of Mohammad. After they reached Buton, this became the centre from which they began to spread the faith to the east. One of the seven was the wali (holy man) who brought the first Qur'an to Ujir (Wellfelt and Djonler 2019). While the other west coast villages looked to the VOC as a protector in the volatile world of southern Maluku, the patchiness of Dutch control of the region made Islamic networks a viable option for a trade-oriented community such as Ujir.

A dominant figure in the Islamization process of the 1650s-1670s bore the very name Tamalola. The relationship between the oral order of events and the documented chronology is often trickier than it might at first seem. It is

28 VOC 1275 (1670), Report, 20 March 1670, f. 379v. A passage from 1670 in VOC 1281, f. 378 states that Moorish (namely, Muslim) qadis and modims had been active in Ujir during the last 19 or 20 years.

29 VOC 1271 (1668), Banda report, 1668, f. 448. It might be significant that the request was made soon after the fall of Makassar to the VOC coalition in 1667, making the Dutch establishment the main player in the area to approach. We are grateful to Simon Kemper, Leiden, for pointing out this possibility.

30 VOC 1301 (1675), Letter, Wokam to Banda, 11 October 1674. 
possible that Ujirese tradition could have telescoped several members of a lineage into one single Tamalola. A contract with the Arunese chiefs on the west coast from 1658 mentions an orangkaya Tamalola of Ujir, who at that time declared his interest in receiving Christian baptism. ${ }^{31}$ However, his position on spiritual matters would soon change drastically. A document from 1670 relates that the Governor of Banda found reason to admonish the Arunese chiefs for their "confused/chaotic government", as he put it. He therefore summoned a number of chiefs, among whom were the "Moors" (Muslims) Maytoby from Wamar and Tamalola from Ujir. Tamalola was severely reprimanded for the behaviour of his fellow villagers, more particularly that of the orangkayas, qadis, and modims (muezzins). These leaders had tried to stop the children of heathen parents attending the Christian school in Wokam that had been in operation since about 1659. By 1674, moreover, Tamalola was rivalling the educational efforts of the VOC by co-operating with an Imam in Ujir, who established a Muslim school for forty pupils from various settlements. ${ }^{32}$ Apart from its commercial activities, the VOC felt it had a spiritual obligation in the Indies, or at least in those parts not professing a "world" religion. This attitude had actually been enshrined in the charter granted by the metropolitan Dutch authorities. Schools were the normal means of imposing a sense of the Reformed Christian religion among Indonesian groups. While the Company normally observed a live-and-let-live policy in religious matters, non-Muslim areas were to be converted as far as this was possible, and Muslim assertiveness in mission areas was unacceptable (Niemeijer 2001). The governor ordered Tamalola to tell prominent Ujir Muslims that they must not disseminate their "sect" or hinder the schoolchildren - otherwise the VOC would expel them from Ujir. ${ }^{33}$ Here we seem to have a succession of representatives of a prominent Muslim lineage, further highlighting the effects of the demise of the latter-day Tamalola.

Apart from the telescoping of several generations into one figure, there is also a tendency in local oral tradition towards the fragmentation of historical knowledge (see Vansina 1985). When enquiring about traditions on Ujir today, a number of seemingly disconnected stories are told about the past. One such theme is relations with Muslim islands in other parts of Maluku, Gorom, and Tidore. A pela (alliance) between Ujir and the important village Amar on Gorom was of long standing. Allegedly, Amar was originally the name of a king from Gorom who ruled over Aru, Kei, and Seram. Likewise, there was a pela with Tidore, the staunchly Muslim sultanate in the north and the Ujirese had assisted the ruler of Tidore in resisting the Dutch colonial presence. In return, the king of Tidore had visited Ujir and bestowed a sword on the locals

31 ANRI Banda: 45-1, Report dated 1796, Arsip Nasional, Jakarta. Thanks to Ligia Giay, Murdoch University, for pointing out this report to us. An Ujirese orangkaya Bomyque is mentioned in 1646, possibly Boiniki, the father of Tamalola, of the oral accounts. VOC 1159 (1646), Relation by J. Vertregt, sub 19 March 1646.

32 VOC 1301, Report, May 1674.

33 VOC 1281, Banda dagregister, sub 9 December 1670. 
as a symbol of their close-knit alliance. ${ }^{34}$ In fact, these fragments of information all refer to a violent sequence of events in which Tamalola was a catalyst.

\section{UJIR WITHIN THE VOC SYSTEM}

A VOC base consisting of a fort and a tiny garrison evolved on Wokam in the late seventeenth century. As were the other Company domains in southern Maluku, it was under the supervision of the governor in Banda. In spite of the mercantile monopoly policy championed by the VOC, and the resulting discontent, dramatic events were few and far between in the period from the 1680 s to the 1780s, at least from a Dutch perspective. As was the situation in most of Indonesia before the early twentieth century, local communities were subjected to indirect rule, and might even be considered subordinated allies of the Dutch, their position ratified by the exchange of formal contracts. The presence of the Dutch ensured that at least some information in the bulky VOC records from Banda is devoted to Aru. The reasons are obvious. Aru was considered primitive, but it was nonetheless economically significant. Certain species of trepang (sea cucumber) were harvested around the coasts. These sea creatures were boiled, dried and smoked in a laborious process before being sold as a delicacy to wealthy Chinese who used it for soups and ragouts (Bik 1928: 69-72). Turtle-shell, birds-of-paradise (Paradisaea apoda) and edible bird's nests expanded the number of the luxury products on offer. In fact, Ujir was known as the best place to obtain king birds-of-paradise (Cicinnurus regius), one species of bird-of-paradise (Valentijn 1726: 313). In the seventeenth century it was discovered that the oysters found off the east coast (the Backshore) yielded pearls, and pearl-diving had become common by the late VOC period. Other less enticing but nonetheless important articles for export, such as sago, pulses, beans, hogs, poultry and dugong meat were also for sale (De Klerk 1894: 29-30).

All these assets lent Aru a certain importance, to the Dutch as well as Asian merchants. The luxury products ended up in distant lands: the trade in the skins of birds-of-paradise, prepared to be used as panaches, was carried on with Persia and the Ottoman Empire, and the bird's nests and trepang were consumed in China and the Chinese enclaves in Southeast Asia. Pearls were, of course, hard cash on a global level (Bik 1928: 73). By the late seventeenth century, the VOC burghers on Banda had formally obtained the exclusive right to trade with the Arunese but their movements were circumscribed by the local weather conditions. In the easterly monsoon, in late spring-summer-early autumn, Aru was difficult to reach from Banda. It is clear from the records of the eighteenth century that it could take up to half a year for news from Aru to travel the 500 kilometres to the main post on Banda - approximately the time required for a ship to sail from Europe to the East Indies. ${ }^{35}$ Therefore the possibilities for visits by unauthorized merchants were limited. The peoples of South Sulawesi, usually known as Makassarese by the Dutch, were highly

34 Jafar Hatala, Ujir, personal communication, 9-4-2016.

35 Comité Oost-Indische Handel en Bezittingen, 84 (1795), 2.01.27.01., f. 100. 
competent sailors who more often than not ignored the monopoly. Their presence on the coasts of Aru was increasingly felt in the eighteenth century (Bleeker 1858: 266). The same claim can be made for the Goromese. East Seram and the islands to the east, such as Keffing and Gorom, were the hub of a comprehensive trading network, known since the sixteenth century. Slaves and natural products were obtained in Papua, and the trading route used by these people went via Aru and Kei to Timor, Sumbawa, Lombok, Bali, and even the coast of Java (Ellen 2003: 54-113). While there might have been competition between merchants from Maluku and South Sulawesi, they shared a religion, Islam, in common with the outward-looking society of Ujir, and this formed an ideological basis for anti-colonial sentiment. The Christians in Wokam, Wamar, and Maekor, including several chiefs, were seen as a counterweight to the Muslim Ujirese, but they were few in number. By 1782, a total of 236 Christians were living in the main settlements of these three islands, far fewer than the Muslims in Ujir and its adjacent villages Samang and Fangabel (on Wokam Island). In 1787, these villages could produce 380 fit men, suggesting an overall population of 1,500 people or so. ${ }^{36}$ The so-called Alfurs of the interior and Backshore were considered "barbarian and cruel" and were unreliable subjects of the VOC. ${ }^{37}$ As a report from 1796 says:

It would seem that the people of Kowiai, a territory situated on the Papuan coast [Bomberai Peninsula, under Tidorese influence], support the Arunese. The former are numerous, and the Backshore people, or Alfurs of Aru, are no less so, since both these lands abound in people, and the tracks leading there are entirely inaccessible to Europeans or armed people; and so, it is not possible to transport even light artillery thither, because of the many innumerable rivers that run thither and yon, and are deep or shallow here and there. Between these lie deep or shallow morasses, not to speak of the forests and kolzen (rotsen, rocks?) that stretch out for miles and are impenetrable and impossible to ignore. It is true that there are secret roads here and there, but they are quite unchartered, and nobody knows about them except the wild, uncivilized Alfurs, or the inhabitants of the hinterland, who seldom or never visit the inhabitants of the land on the foreshore, where the Company post is. It think that if one were to go a few miles past the land of Aru Wokam, and wanted to go farther or into the hinterland, it would be completely impossible; for none of our people has ever been there, and for them, this would be the most dangerous undertaking. ${ }^{38}$

Some "Alfur" groups fell loosely under the control of the Ujirese, and delivered natural products for external commerce to them. The interesting web of strategic alliances and dependencies between Ujir, the inaccessible but

36 VOC 8034 (1787), Witness account by Nicolaas Harmansz and his kin.

37 VOC 8028 (1782), f. 54-55. Alfurs was the somewhat derogatory term used for supposedly primitive peoples in the Malukan region, especially Seram, and is reflected in the geographical term Arafura Sea.

38 ANRI Banda: 45-1, Report dated 1796, Arsip Nasional, Jakarta. We are grateful to Antoinette Schapper, Leiden, who explained the location of Kowiai. 
resource-rich "Alfur" hinterland, and the overseas peoples of Papua, would play an important role in the conflict lines of the late eighteenth century.

\section{TENSION HEIGHTENS}

A number of issues, spanning different spatial levels, disturbed the peace in Aru towards the late eighteenth century. Firstly, the monopoly meant that the VOC burghers offered prices for products that were lower than those offered by unlicensed Asian traders. Banda itself was suffering from dwindling nutmeg production, the coup de grâce delivered by a hurricane exacerbated by an earthquake and a tsunami in 1778. Almost all the nutmeg trees were decimated, and the incentive for commercial trips to the South-western Islands (Kei, Tanimbar, and Aru) dwindled. All this reinforced the "illegal", and from an Arunese point of view profitable, trade carried out by Makassarese and others. When the Dutch tried to restore the Banda trade and drive the "smugglers" from the seas around 1780, the local populations were naturally displeased, since their incomes decreased (Bleeker 1858: 266-267).

Secondly, discontent with the Dutch presence in various parts of Maluku after 1780 led to the growth of a rebel movement. The focal point was Prince Nuku of Tidore, who tussled with the Dutch for a quarter of a century. The catalyst was dynastic: Nuku felt that his branch of the sultan's family had been poorly treated by the Dutch. However, his movement expanded from a personal quarrel to involve various parts of Halmahera, the Papuan Islands and East Seram, where Islam was not always a common denominator. Although Nuku's movement was marked by anti-Christian and anti-European features, it was still allied with the British in the French Revolutionary Wars after 1795, when the Netherlands became a dependency of France and consequently an enemy of Britain (Widjojo 2009).

Thirdly, the Dutch eventually fell foul of Ujir, as can be seen from a few lengthy reports from 1787 and 1788. The rumblings had already begun in 1772. A lesser chief (orangtua, an elder) of Ujir called Bolbol was involved in a serious case of manslaughter. ${ }^{39}$ Members of the small token garrison in the Wokam fort were assaulted and four soldiers were murdered. Three other men were wounded and later died. Retaliation was slow, but two years later the Dutch corporal Johannes Olewijn managed to arrest Abay, one of Bolbol's sons. The enraged Bolbol travelled to Wokam and demanded that his son be set free, if not he would besiege and ravage the fort. A dramatic incident now followed. Olewijn refused to yield and an Arunese called Kay Lauw assisted him by shooting Bolbol dead and cutting down one of his other sons. Bolbol's head was severed from his body and taken in triumph to Banda Neira. Abay was exiled to Batavia. ${ }^{40}$

The matter was not as straightforward as this outline would suggest, however; the VOC documents gainsay each other, highlighting the problem

39 As was Tamalola, Bolbol was the name of several members of an Ujirese-speaking lineage. There are chiefs carrying that name found in the sources since the mid-seventeenth century.

40 VOC 8034 (1789), Report, 30 July 1787, f. 115. 
of using one-sided colonial sources, even when they are contemporary with the events they describe. In 1788 the Dutch second-in-command in Banda, s'Gravezande, tried to dissuade the chiefs of the Kei Islands from following the rebellious example of Ujir and alleged that the incidents then afflicting Aru were in fact the result of infighting among the islanders. In this version, the Ujirese had supposedly expelled Bolbol from their island. The chief then went to live in Samang, an Ujirese-speaking village on Wokam Island and began to befriend the so-called Alfurs of the east coast who delivered many of the valuable export products to the west coast. The Ujirese for their part began a campaign of defamation that eventually fooled Corporal Olewijn, who believed that Bolbol was about to besiege the Dutch fort with his Alfur warriors. The corporal therefore took the ill-fated decision to invite Bolbol under the pretext of friendship and shot him down. ${ }^{41}$ The two versions of Bolbol's end are strikingly dissimilar, although it should be recalled that the 1788 version has a strongly rhetorical purpose. In fact, Bolbol is remembered in Ujirese tradition to this day as an important ancestor and his name was given to one of the three bén of Ujir [Jariri] when they merged and were renamed in the mid-twentieth century.

The incident, whatever its ins-and-outs, did nothing to appease the Ujirese. They seemed to grow ever more unruly and their resentment was the cause of the voluntary exile of a few strongmen. The next year, 1775, their "priest" (probably Imam), Badir, fled to Kei. The VOC did not have a post on the Kei Islands, that consisted of several small principalities and took care of their own affairs. The orangkaya of one of the Ujirese kampungs, Abdul, likewise voted with his feet and went to Papua where the Dutch as yet had no presence. Aided and abetted by some Papuans, he launched raids on Aru. ${ }^{42}$ In one version, the Ujir-Papuan relationship began when an Imam from Papua, probably from one of the Muslim sub-principalities under the suzerainty of Tidore, was captured by Alfurs of the east coast. ${ }^{43}$ The Ujirese covered up the issue by telling the Dutch that the imam had passed away in captivity. In fact, they took him back to Papua safe and sound, thereby commencing an alliance between the two ${ }^{44}$ If the story is correct, it underlines the role of Islam in forging strategic co-operation, even in these easternmost outposts of the Islamic world.

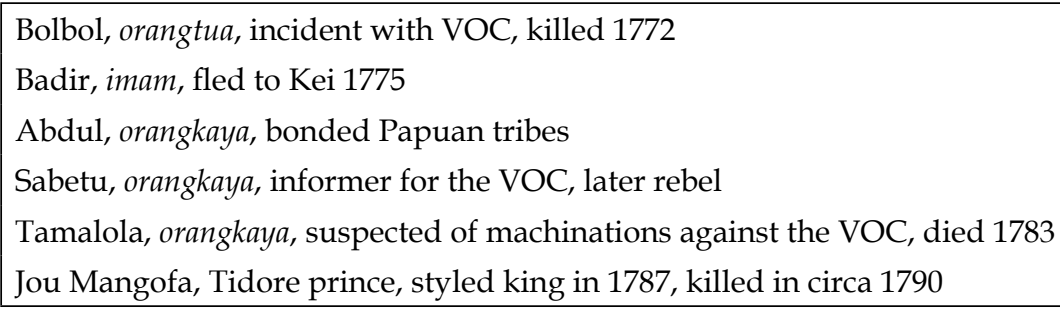

Table 2. Leaders in Ujir, late eighteenth century.

41 VOC 3864 (1789), Secret letter, 6 December 1788.

42 VOC 8034 (1789), Report, 30 July 1787, f. 115.

43 For early Islamic inroads in Papua, see Warnk 2010.

44 VOC 3864 (1789), Secret letter, 6 December 1788. 


\section{AN UNTIMELY DEATH}

The turbulence that the Bolbol incident had engendered was in no way assuaged by Tamalola's death in captivity a decade later, in 1783. The most that can be said is that the Dutch were careful not to enrage the Ujirese even more; Tamalola's captors Willems and Clements did not think an attack on Ujir warranted, neither should the settlements be burned nor the fruit trees be destroyed, since there were also "good-natured people" there. A report from 1788 highlights the deteriorating position of the Company in South Maluku. People from Ujir strengthened their position on Aru by enjoining their allies from Notan on the north side of West Papua to raid the Batuley people on the eastern side. Many Batuleyese were captured, but later released on condition they conclude an alliance with Ujir. ${ }^{45}$ In the light of the kin relations between families in Ujir and Batuley in modern times, there might be more to the story than what was written down by the Dutch. Meanwhile the fugitive Imam Badir, alleged to be Tamalola's principal "accomplice", remained safely ensconced with the rebels on Kei. Most of the Keiese sympathized with the Nuku movement, interestingly with the exception of the descendants of the Bandanese in Eli and Elat - whose ancestors had once fled from the Dutch genocide in Banda in 1621, again pointing to the need to problematize the label "Muslim".

The dire consequences of Tamalola's death are related somewhat differently in the various Dutch sources. According to an 1858 account, the Ujirese were initially unaware of the fate of their revered leader. A few years after the event, a trader from Ujir with close ties to Tamalola arrived on Banda. Great was his astonishment when the locals told him about the sad death of a person for whom he felt boundless respect. The embittered trader swore to exact vengeance on the despicable Dutch and returned to Aru. Back in Ujir he recounted the sufferings of Tamalola in gory detail, and incited his compatriots to take the first opportunity to avenge the treason and make the Dutch pay (Bleeker 1858: 268).

This story is not found in the contemporary sources, but these do confirm that Tamalola's friends strove for revenge. By August 1784, the Ujirese were still unwilling to appoint a new orangkaya to take Tamalola's place. They told a visiting trader that they intended to take the matter into their own hands. The commander of the small garrison in Wokam, Anthony Bode, got cold feet as he realized that matters would end badly on Aru. He therefore applied to be replaced. The Dutch understood that the Ujirese had colluded with people from Seram and Gorom and pointed out Ujir was a danger to Aru and an impediment to the trade. From year to year, the Dutch position in Aru seemed steadily to deteriorate. ${ }^{46}$ 


\section{A REBEL KING IN A STATELESS SOCIETY}

Turning now to the eruption of the actual physical hostilities, the most detailed accounts in the colonial archives are two narratives dictated by a few Arunese chiefs in Wokam and Wamar, who were Christian and hostile to those who rebelled against the Dutch order. These chiefs had escaped from Aru with some difficulty and dictated their stories to Company clerks. While their perspectives should be taken with a grain of salt, what they had to say substantially agrees in the details, and at least give a partial representation of an Arunese view on Aru. From their narratives, the following picture emerges.

By 1787, a brother of Nuku of Tidore was residing on Smaller Kei where he surrounded himself with people who had fallen out with the Company. From his stronghold there, this prince sent some of his trusted men, including two Goromese chiefs, to Aru. On their arrival in Wokam, the envoys tried to persuade the Christian orangkaya to champion the Tidorese cause, or suffer the consequences. The Tidorese prince was adamant that he would expel the Europeans and establish his residence in the Aru Islands. However, the orangkaya was not open to persuasion. The envoys from Gorom then turned to the Ujirese and suggested that they attack all merchant ships from Banda. The Ujirese heeded their call and began to harry the burghers on their vessels. ${ }^{47}$ This was just the beginning. The orangkaya of Wokam, Nicolaas Harmansz, provides a lively account of what followed.

On 2 April 1787, he [Nicolaas Harmansz] was in the hinterland of Pulau Mariri collecting trepang, when he heard from people from Wokam that the people of Ujir, Fangabel, and Samang intended to come to his negeri and the post, and massacre them if they did not submit. He immediately went back to the post in Wokam with his followers. When he arrived there, the people of the negeri Fangabel and Samang dispatched a few men to the orangkaya. They said that, if he turned the European garrison over to their people, they would send 200 men to protect negeri Wokam and take care that no harm befell him or anyone else. However, he refused saying that he wanted to remain loyal to the Noble Company, presenting them with money to buy them off from committing any ill-intentioned deeds against the Europeans.

When the Moors received this negative reply, they lost no time attacking burgher ships that were robbed. Thereafter, on 14 April, in the morning before daybreak they fell upon negeri Wokam with 300 men, Ujirese men from Fangabel, Samang, and Goromese. They violently destroyed everything and set it alight. They also assaulted the post with its small garrison and burned it down too. Because of this, the Europeans as well as the orangkaya and his Christians were reduced to a state of utter terror and confusion. They were forced to abandon everything and flee into the forest. Sergeant Engelhard and his men, ten persons in all, took as many weapons, plus some powder and bullets, as possible from the magazine at the post. They intended to join the Christians later, and repel the rebels. 
After remaining in the forest for two days, they heard from other Christian refugees that not only the post, but also the church had been destroyed. The rebels did not desist, and once again sent men to the orangkaya in the forest where he was living with the Europeans. They offered him a cloth and a white kerchief as token of peace, if he abandoned the Europeans and handed them over. They also enjoined him to become a Mohammedan instead, since he could no longer depend on the Noble Company, as it had been exterminated in all their possessions, and they must henceforth be governed by the king of Tidore, whose immense power must surely overwhelm all the Company. However, he declined the offer and burned the cloth and white kerchief. When the Moorish envoys saw this, they threatened him and the Europeans with certain death and withdrew.

It was on 17 April that their hiding place was unexpectedly attacked on all sides, betrayed by several of his own compatriots together with a Stephanus of Ambon who had come to reside in Aru some years ago, and also Cabouwl Moor, a soldier in the service of the Noble Company. Seeing that he could no longer escape, the orangkaya and the European sergeant J.P. Engelhard, the corporals J.A. Finck, Anth. Hansen, the soldiers Barend Krook, J. de Zilva, and the artillerists Dirk Bakker and Isaak Parenoesa, fell into the hands of the rebels. ${ }^{48}$ They were treated in the most degrading manner, tied up and dragged along to the negeri Fangabel and Samang. The orangkaya later heard that the Europeans Engelhard, Finck, Hansen, Krook, and Bakker had been murdered there on 1 May. They cut the hair of the orangkaya and threatened him on 3 May. However, they subsequently granted him, his wife and children their lives, and also the soldiers De Zilva and Parenoesa. The first served as slave among the Ujirese, the second in Fangabel.

The Moors of Ujir, Fangabel, Samang, and Wasir said to the orangkaya that, if he was asked about this later, he could say that the blood of the orangtua of Samang, Bolbol, who had been shot by the Europeans while his son had been sent to Batavia, and their orangtua of Ujir, Tamalola, was now avenged. ${ }^{49}$

The millenary rhetoric used by the rebels requires some closer examination. The VOC possessions allegedly had been "exterminated", and the future lay in the hands of the "King of Tidore", meaning Nuku. The days of the Christian Europeans were over, the age of the righteous Muslim ruler had arrived. Although the European soldiers were killed, those with an Asian background were spared, indicating that skin colour was in some respects decisive. Another report by the senior orangkaya Coenraad Abraham Schipio of Wamar, speaks of religiously motivated violence. One of the Christian orangkayas set sail for Banda in an orembay (boat) but he was driven off course and intercepted by a rebel junk from Gorom. Those prisoners who could speak Malay were deemed to be Christians (as Malay was the language of religious instruction) and they had their feet bound and were cast into the ocean, while those who could not

48 According to another report, it was the Jobulegang Alfurs on the Backshore who after some hesitation had given in to the Ujirese demands, and assisted in handing over the VOC soldiers. 49 VOC 8034 (1787), Witness account by Nicolaas Harmansz and his kin. Bolbol and Tamalola were otherwise known as orangkayas. 
were taken to Bali and sold as slaves. ${ }^{50}$ Although Schipio could only tell this harrowing story second hand, he obviously wanted the Dutch to believe that the rebellion had a pronounced Muslim-versus-Christian edge.

Meanwhile, the Backhore settlements, populated by supposedly primitive "Alfurs". The majority were allied with the rebels, the principal exception being the pearl-diving island Barakai in the south-east. The Ujirese, who presumably understood that the massacre would provoke a Dutch retaliation, sent a hurried message to Nuku's brother in Kei and asked him to honour his promises of assistance. Indeed, the Tidorese prince did write a letter addressed to his famous brother, who was in Seram at that moment, and gave it to the orangkaya of Ujir, asking him to show it to Nuku who would then send reinforcements. He did indeed set sail for Aru in person on his korakora, bringing with him a large number of Alfur retainers from Tobelo and Tobaro in North Maluku. ${ }^{51}$ There he was hailed as king under the name Jou Mangofa and began to issue royal orders and bring the various settlements under his governance. He demonstrated his triumph over the defeated Company with a display of topsy-turvy symbolism. The Company prisoners were demoted to servants who had to walk behind him carrying his parasol, betel box and keris, whereas a few Asian prisoners were made secretary and the helmsman of the royal korakora. ${ }^{52}$

At this moment we should pause to reflect on the nature of anti-Dutch resistance. Various factors surface in the colonial records, although the writers might not have been quite aware of their significance. That a large part of the Alfurs quickly left the Dutch fold and supported Ujir points to economic reasons: a more open access to Aru by Asian traders not under the VOC umbrella meant better bargaining prices for the luxury products, an advantage extended to other networks of loyalties. The records in these years mention Mandarese, Wajorese, Sumbawans, and Bugis who approached Seramese traders in order to obtain the valuable trepang. ${ }^{53}$ These people also visited to Aru itself, to Tanimbar and other eastern destinations on an annual basis, unencumbered by any threat from the moribund Company. ${ }^{54}$ Nevertheless, the local inhabitants' loyalty to Ujir and King Jou Mangofa was conditional. The setting up of a royal court on Ujir by the Tidorese prince especially might not have been in their interests. Aru was a relatively non-hierarchical society that had never known royal rule, although admittedly Jou Mangofa might be seen more as a charismatic "big man" than a conventional monarch. ${ }^{55}$ His task was to bring unity to the fragmented settlements that opposed the colonial

50 VOC 3817 (1789), Relation by Coenraad Abraham Schipio, old orangkaya of Wamar, 14 May 1788.

51 VOC 3817 (1789), Witness account by Pieter Pauhuta, 25 June 1788.

52 VOC 3817 (1789), Relation by Coenraad Abraham Schipio, old orangkaya of Wamar, 14 May 1788.

53 VOC 8034 (1789), Report, 12 April 1787, f. 129. Mandar and Wajo' are situated in Sulawesi.

54 VOC 3864 (1789), Missive, 22 September 1789.

55 For the social structure of Aru, see in particular Riedel 1886 and Spyer 2000. 
order. However, as his position was conditional any orders or impositions laid down by Jou Mangofa could easily have met with resentment. In fact, by May 1788 the Dutch had already fathomed that the Alfur population, who were the suppliers of trade goods, hated the Ujirese and sympathized with the Company people. Lately, they had not dared to trade their products for fear of the Ujirese and their accomplices, in particular Gorom. ${ }^{56}$ The subsequent events also showed that the Alfurs of Batuley and other eastern communities were quick (temporarily) to revert to the VOC when and if the opportunities to do so presented themselves.

Secondly, on the discursive level, the role of Islam is undeniably present. Tamalola was remembered as a prominent man of religion, a fact that explains some of the intense hatred felt for the Dutch traitors. This situation concurs with external influences. One report makes no bones about the fact that Nuku's men from Maba, Weda, and Patani on Halmahera, together with some Seramese, arrived in Aru to "take care of the Mohammedans of the small island of Ujir" ${ }^{57}$ An occasional anti-Christian sentiment is observable as the Ujirese tried to persuade Christian Arunese chiefs to convert to Islam. However, not too much should be read into this; in times of peace the relations between Ujir and Christian enclaves could even be cordial.

The end of the anti-Dutch rebellion is a story rich in drama. For our purpose it will suffice to sketch the outlines. The economic importance of Aru in this part of Indonesia, coupled with a commitment to avenge the massacre, was the motivation behind the repeated annual military expeditions to Aru in the years 1788-1791. The conflict also merged with the effort to put down the Nuku movement. At first the Ujirese and their allies could more than hold their own. A convoy from Banda was crushingly defeated by the hongi (fleet) of Jou Mangofa in 1788, and a large number of vessels were lost. ${ }^{58} \mathrm{~A}$ second expedition landed in Ujir in the spring of 1789 but fared even worse. The Ujirese had ingeniously blocked the canal leading to the settlement, erected strong fortifications and distributed caltrops. After a bloody battle with large casualties on either side, the Dutch returned their heads held in shame. Despite their victory, it was obvious that the rebels were living on borrowed time. The people of the Kei Islands refused to assist them and the resources on tiny Ujir were on the verge of total depletion. The renewed loyalty of the Alfurs of the Backshore was bought by the Dutch, and they began to track down the Ujirese wherever they could. ${ }^{59}$ A third VOC expedition in March 1790 was a partial success: Ujir was taken without resistance, but the population seized the chance to flee in boats lying ready for them on the eastern side of the island. The Dutch commander decided to erect a fortification on Ujir, but it was shoddily built and inappropriately situated on the site of the mosque

\footnotetext{
VOC 3817 (1789), Report, 28 May 1788.

VOC 3817 (1789), Report, 28 May 1788.

VOC 3817 (1789), Witness account, 9 May 1788.

VOC 3864 (1789), Secret missive, 22 September 1789.
} 
(see Image 3).$^{60}$ King Jou Mangofa was killed about this time under sinister circumstances, an event that probably spelled the death-knell of the rebellion. ${ }^{61}$ His retainers from North Maluku must have retreated since we hear no more about them. Finally, a fourth expedition in 1791 was successful. The Ujirese chiefs, who had scattered to various places in Aru, surrendered without any further ado, and were forced to sign a contract. ${ }^{62}$

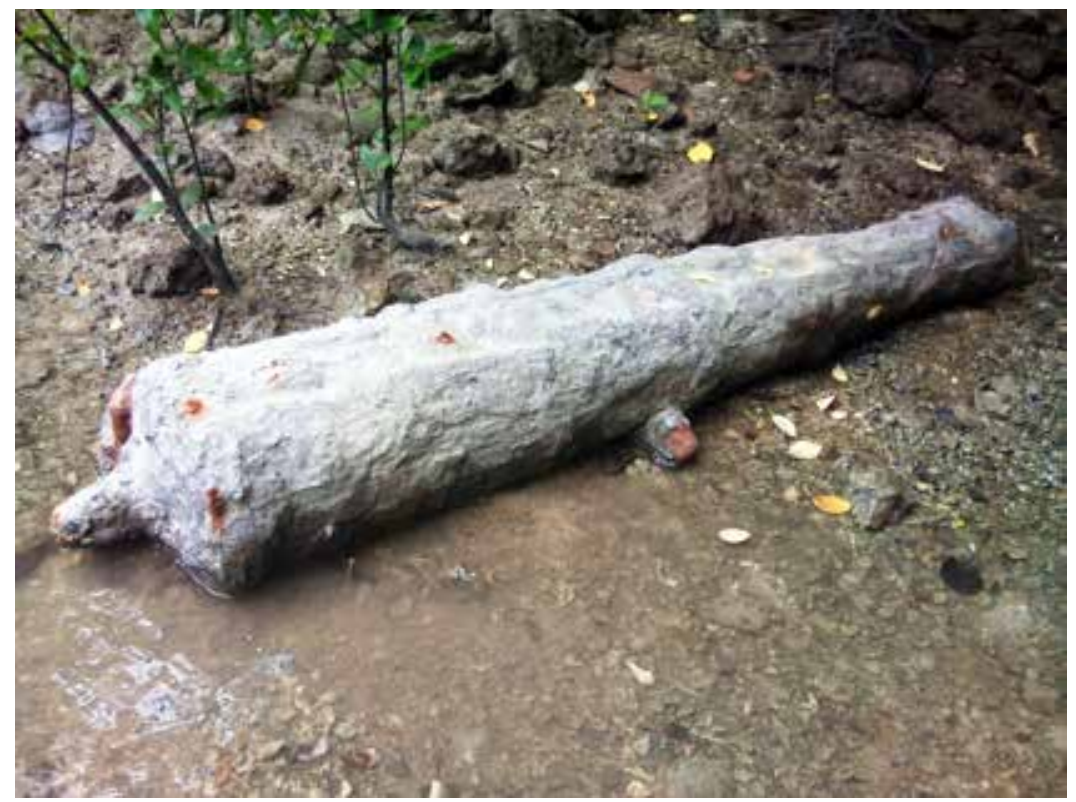

Image 3. A cannon lies buried in mud at the bank of the sungai (natural canal) in Ujir, close to the ruins of the old mosque - presumably the easternmost mosque in the world in the early-modern era (photograph by Hans Hägerdal).

Although the manpower of Ujir had been heavily depleted and the little island did not cause the Dutch any further trouble, peace did not descend on Aru. Resistance soon flared up on the Backshore and more or less persisted until this part of Maluku was captured by the British in 1796. In the next year, the movement of the British-allied Nuku triumphed as his forces took Tidore and ousted the Dutch-backed Sultan (Katoppo 1984:117-118). Simultaneously a number of Dutch fortress along the coasts of Asia fell to the might of Britain. The inglorious end of the VOC followed shortly afterwards, at the end of 1799. Incidentally, the British administration drew up a singularly detailed report on Banda trade that gives an idea of the economic stakes that caused the VOC to dispose of Bolbol and Tamalola and dispatch four costly expeditions in order to retain Aru. For an assortment of textiles, cutlasses, elephant's tusks,

60 VOC 3910 (1790), Secret report, 8 June 1790, f. 12-3.

61 Katoppo 1984: 79, 84, says he died in battle on Ujir, but details are lacking in reports of the 1790 and 1791 expeditions.

62 VOC 3943 (1791), Secret report, 16 June 1791, f. 84-98. For the contract, see Schapper 2018. 
porcelain, gongs and the like, each year the traders would bring back up to 650 piculs (some 40,000 kilos) of trepang, pearls for 50-60 dollars, 2-300 birdsof-paradise, a little turtle-shell, and a few slaves (Miller 1980: 49-50).

\section{CONCLUSIONS}

This study has followed the vicissitudes of a tiny Malukan community from two perspectives. Firstly, we have seen how a stateless, internally divisive village complex was able to mobilize resources under duress and rise in opposition to the colonial overlord in the Aru Islands. Secondly, it has shown that the locals of Ujir were able to tie into wider regional forms of resistance, as indicated by the extensive network of pela alliances with Papua, SeramGorom, and eventually Tidore, a prelude to the rebellion of 1787-1791 that went on to install a short-lived kingship with millenarian ambitions. While the rebels fought alongside the prestigious Muslim Tidore dynasty, their defiant war cry spoke of local grievances closer to home: "Where is Bolbol? Where is Tamalola?". ${ }^{63}$

This leads us to the position of the Tamalola figure, and other historical characters in local tradition. Their stories provide a rather different historical landscape from that offered by the colonial narrative, as they are detemporalized, set in a vague past, and in part stress other historical processes. Nevertheless, the two reinforce each other in various ways. The origins of Tamalola's bén are connected to immigration from Luang, an important theme in many South Malukan societies, as well as to the establishment of Ujirese leadership and with the adoption of Islam. Furthermore, fragmentary stories about the life and abode of Tamalola demonstrate the functionality of preserving his memory over the centuries. At the same time, the divisive nature of Ujir society again needs to be stressed: there was no master narrative, and some details about the immigrant bén were questioned by locals. Nevertheless, the oral references to Luang, Buton, Gorom, and Tidore point to networks that the Dutch either did not know much about or did not bother to record. The Ujir connectivities with distant places in or even beyond Maluku were underestimated by colonial observers, and are merely hinted at here and there.

From Dutch sources, we have followed the rise of a Muslim community after the mid-seventeenth century, in which at least two Tamalola, living one century apart but likely belonging to the same lineage, played prominent roles - the first presiding over Islamization, the second cast as the "Oracle of Aru" and likewise an important Muslim figure. The VOC records concur with oral traditions in that they, on one hand, reveal the deep divisions within Ujir itself, not to speak about the various Arunese settlements. On the other hand, they demonstrate how resentment aroused by the Dutch deposition of Tamalola and his fellow chief, Bolbol, led to a manifestation of general resistance that happened to tie in with the Tidorese dynastic movement. While Tamalola is a shadowy figure in many respects, his spiritual and political status transcended 
that of his own bén, as he was actively invoked as the rationale for the uncompromising violence against the VOC soldiers and merchants. The acts of revenge committed in his name resulted in the unique attempt to introduce an Arunese kingship, making use of the Malaku-wide prestige of the age-old Tidore dynasty. The eventual failure of all this was hastened by the deeply divided positions of the Arunese; various chiefs and tribal groups found their interests better served by the presence of the VOC, and actively resisted the rebellion. At the bottom of these contradictions lie the ambivalent consequences of colonial economic and political control. In the polycentric Malukan world of autonomous and often antagonistic settlements, the Europeans could act as a force for order, a stranger king in a position to mediate impartially. ${ }^{64}$ This role was, however, partly undermined by its servants intrusive ways of regulating trade and prohibiting the free movement of high-cash export products. When resistance erupted, it spanned interlocking regional, sub-regional and local levels of agency, epitomized by the fates of Tamalola and the Tidore prince.

Meanwhile, the events that the written sources help us date to 1790 are remembered as the beginning of colonial rule. In 2013, while walking along the path towards the old village, the most senior man in Ujir, Jafar Hatala, told the story of the "Portuguese" [that is Dutch] attack on Ujir. One "Portuguese" leader was killed, Jafar pointed to his grave, but in the end the Ujirese were defeated. Since that day and in the centuries that followed, the Ujirese had to obey foreign rulers. ${ }^{65}$

\section{BIBLIOGRAPHY}

\section{UNPUBLISHED SOURCES}

Müller-Wismar, Wilhelm, Ethnographic fieldnotes, held by the Museum of Ethnology in Hamburg.

ANRI Banda, Arsip Nasional, Jakarta.

Comité Oost-Indische Handel en Bezittingen, Nationaal Archief, The Hague, access number 2.01.27.01.

VOC Archive, Nationaal Archief, The Hague, access number 1.04.02.

\section{PuBLISHED SOURCES}

Bik, A.J. 1928. Dagverhael eener reis, gedaan in het jaar 1824 tot nadere verkenning der eilanden Kefing, Goram, Groot-, Klein Kei en de Aroe eilanden. Leiden: A.W. Sijthoff.

Bleeker, Pieter. 1858. "De Aroe-eilanden, in vroeger tijd en tegenwoordig", Tijdschrift voor Nederlandsch Indië 20-1: 257-275.

64 For the stranger king syndrome in insular Southeast Asia, see in particular Henley 2002; Lewis 2010.

65 Interview with the late Jafar Hatala (d. 2016) in Ujir, 2013. 
Coolhaas, W.P. 1960. Generale missiven van Gouverneurs-Generaal en Raden aan Heren XVII der Verenigde Oost-Indische Compagnie, Vol. I: 1610-1638. Den Haag: M. Nijhoff.

Coolhaas, W.P. 1971. Generale missiven van Gouverneurs-Generaal en Raden aan Heren XVII der Verenigde Oost-Indische Compagnie, Vol. IV: 1675-1686. Den Haag: M. Nijhoff.

Corpus. 1907. Corpus diplomaticum Neerlando-Indicum, Vol. I. 's-Gravenhage: M. Nijhoff.

Dagh-Register. 1887-1931. Dagh-Register gehouden int Casteel Batavia. 31 volumes. 's-Gravenhage: M. Nijhoff, Batavia: Landsdrukkerij.

Dijk, J. van. 1859. Twee togten naar de Golf van Carpentaria. Amsterdam: Scheltema.

Ellen, Roy. 2003. On the edge of the Banda zone; Past and present in the social organization of a Moluccan trading network. Honolulu, HI: University of Hawaii Press.

Encyclopaedie. 1921. Encyclopaedie van Nederlandsch-Indië. Vol. VII. 's-Gravenhage: M. Nijhoff.

Fox, James J. 1971. “A Rotinese dynastic genealogy; Structure and events”, in: T. Beidelman (ed.), The translation of culture, pp. 37-77. London: Tavistock.

Fox, James J. 2008. “Installing the 'outsider' inside; The exploration of an Austronesian epistemic cultural theme and its social significance", Indonesia and the Malay World 36: 201-218.

Gordon, A. Ross and Sonny A. Djonler. 2019. “Hope and energy at the Arafura Sea shore", Journal of Ritual Studies 33(2): 1-18.

Grijzen, H. J. 1904 "Mededeelingen omtrent Beloe of Midden-Timor", Verhandelingen van het Bataviaasch Genootschap 54: 1-145.

Hanna, Willard. 1991. Indonesian Banda: Colonialism and its aftermath in the nutmeg islands. Banda Neira: Yayasan Warisan dan Budaya Banda Neira.

Henley, David. 2002. Jealousy and justice. Amsterdam: Vrije Uitgeverij.

Hooe, Todd. 2012. "Little kingdoms"; Adat and inequality in the Kei Islands, Eastern Indonesia. PhD thesis, University of Pittsburgh.

Jonge, Nico de and Toos van Dijk. 1995. Forgotten islands of Indonesia; The art $\mathcal{E}$ culture of the Southeast Moluccas. Singapore: Periplus.

Katoppo, E. 1984. Nuku; Perjuangan kemerdekaan di Maluku Utara. Jakarta:Sinar Harapan.

Klerk, Reinier de. 1894. Belangrijk verslag over den staat Banda en omliggende eilanden aan Zijne Excellentie den Gouverneur-Generaal van Ned.-Indië Jacob Mossel. 's-Gravenhage: n.p.

Kolff, D.H. 1840. Voyages of the Dutch Brig of War Dourga. London: Madden \& Co.

Laffan, M. 2011. The makings of Indonesian Islam; Orientalism and the narration of a Sufi past. Princeton NJ: Princeton University Press.

Lewis, E. Douglas. 2010. The stranger kings of Sikka. Leiden: KITLV Press.

Merton, Hugo. 1910. Ergebnisse einer zoologischen Forschungsreise in den südöstlichen Molukken (Aru- und Kei-inseln). Frankfurt am Main: Senckenbergische Naturforschende Gesellschaft. 
Miller, W.G. 1980. “An account of trade patterns in the Banda Sea in 1797, from an unpublished manuscript in the India Office Library", Indonesia Circle 23: 41-57.

Niemeijer, Hendrik E. 2001. “Dividing the islands; The Dutch spice monopoly and religious change in 17th century Maluku", in: Alijah Gordon (ed.), The propagation of Islam in the Indonesian-Malay Archipelago, pp 251-283. Kuala Lumpur: Malaysian Sociological Research Institute.

Pires, Tomé. 1944. “The suma oriental of Tomé Pires and the book of Francisco Rodrigues. London: Hakluyt Society". [Retreived from: https://archive. org/stream/McGillLibrary-136385-182/136385_djvu.txt.]

Riedel, J.G.F. 1886. De sluik- en kroesharige rassen tusschen Selebes en Papua. The Hague: M. Nijhoff.

Saar, Johann Jacob. 1930. Reise nach Java, Banda, Ceylon und Persien 1644-1660. Den Haag: M. Nijhoff.

Schapper, Antoinette. 2018. Wooi Fana; Life and times in Ujir. Jakarta: Yayasan Pustaka Obor Indonesia.

Spyer, Patricia. 2000. The memory of trade; Modernity's entanglements on an Eastern Indonesian island. Durham/London: Duke University Press.

Tiele, P.A. (ed.). 1886. Bouwstoffen voor de geschiedenis der Nederlanders in den Maleischen Archipel. Vol. I. 's-Gravenhage: M. Nijhoff.

Valentijn, François. 1726. Oud en Nieuw Oost-Indien, Deel III B. Doordrecht: Van Braam, Amsterdam: Onder de Linden.

Vansina, Jan. 1965. Oral tradition; A study in historical methodology. London: Routledge \& Kegan Paul.

Vansina, Jan. 1985. Oral tradition as history. Madison, WI: University of Wisconsin.

Warnk, Holger. 2010. "The coming of Islam and Moluccan-Malay culture to New-Guinea, c. 1500-1920", Indonesia and the Malay World 38/110: 109-134.

Wellfelt, Emilie. 2016. Historyscapes in Alor; Approaching indigenous histories in Eastern Indonesia. PhD thesis, Linnaeus University, Växjö, Sweden.

Wellfelt, Emilie and Sonny A. Djonler. 2019. “Islam in Aru, Indonesia; Oral traditions and Islamisation processes from the early modern period to the present", Indonesia and the Malay World 47/138: 160-183.

Widjojo, Muridan. 2009. The revolt of Prince Nuku; Cross-cultural alliance-making in Maluku, C. 1780-1810. Leiden: Brill.

Zahari, et al. 1977. Sejarah dan adat Fiy Darul Butuni (Buton). Vol. 2. Jakarta: Departemen Pendidikan dan Kebudayaan. 